DOI: 10.20472/IAC.2018.038.016

\author{
JANINA KAMINSKIENE \\ Aleksandras Stulginskis University, Lithuania
}

\title{
A FLEXIBLE APPROACH TO THE TEACHING OF MATHEMATICS DURING THE SHORT COURSE
}

\begin{abstract}
:
Flexibility in the teaching of Mathematics is understood as the ability to create more than one method of teaching, which allows to understand and master Mathematics taking into account the specific needs of students and creating a learning environment that encourages thinking and effective work. While working with first-year students, we observe their varying competence and confidence in Mathematics. During the first-year studies, students of agricultural and economic specialties have a short course of Mathematics (3-6 ECTS credit points). Before graduating from school, they had studied Mathematics at different levels of A and B, they took either a school or state examination, or none of them. After the initial diagnostic test, we find very different mathematical fundamentals. Therefore, it is necessary to use several teaching methods that help to understand and learn Mathematics, taking into account the different backgrounds of students, their attitude towards Mathematics, the pace of learning and the way in which they learn. In addition, the aim is to interest students with this subject and to show the possibilities of applying Mathematics.

The paper discusses the structure of the course of Mathematics, the use of methodological strategies, e-learning opportunities and the organization of additional work in order to ensure good mastering of the subject matter of Mathematics.

The answers to questions on what, where, when and how to teach Mathematics are based on practical experience. A graphical analysis method and a method of statistical quantitative analysis of the research data were used in the study. The study presents the results of student surveys on the acceptability and necessity of the measures used to promote learning. The use of mini-tests, the Moodle environment, the practical self-testing tests with answers and the additional weekly counselling were rated positively by students. Video tutorials and applied tasks have attracted only a small percentage of students. Additional Mathematics courses for poorly prepared students did not receive special attention from the students to whom they were intended. Different teaching methods are differently accepted by students. One of the most important things is contacting students during the lectures and practical classes. All other complementary and self-work tools are effective only when students are motivated and they devote time to these studies.
\end{abstract}

\section{Keywords:}

Mathematics, e-learning, Moodle environment, mini-test, flexible teaching. 